Editorial

\title{
Introduction: Alienated Majesty: On Reading as Othering
}

\author{
Adam Zachary Newton
}

Professor Emeritus, Yeshiva University, New York, NY 10033, USA; aznewto@emory.edu

Received: 21 January 2020; Accepted: 21 January 2020; Published: 6 February 2020

Diese Gewähr eines moralischen Gewinns liegt in einer geistigen Disziplin, die gegenüber dem einzigen, was ungestraft verletzt werden kann, der Sprache, das höchste Maß einer Verantwortung festsetzt und wie keine andere geeignet ist, den Respekt vor jeglichem andern Lebensgut zu lehren.

This guarantee of a moral gain lies in a spiritual discipline that ensures the highest degree of responsibility toward the sole thing that can be violated with impunity-language-and that is better suited than anything else to teach respect for all the other values in life.

Karl Kraus, "Die Sprache"1

What hope is there in a book about a book?

Stanley Cavell ${ }^{2}$

The second of the two epigraphs above contemplates the shadow-fate of reinscription: namely, that to read is to repeat another's words, to make them one's own or simply channel them, letting them be. ${ }^{3}$ As the late philosopher Stanley Cavell explains, this is "a question of criticism," which examines the "prompting" of one text by another, disciplinary practice (in his case, philosophy, in ours, literary interpretation) thus taking shape as the "history of such promptings." ${ }^{4}$ Attending to such a prompt-being called upon or called out by the words of another-is the particular concern of these introductory remarks to our essay-compilation.

Insisting that a cultivated attentiveness to language models moral decision, Krauss's loftier rhetoric would seem to more forcefully articulate the spirit of the ongoing humanistic inquiry commonly known as "the ethics of reading." ${ }^{5}$ While the freighted cartography shared by readers and texts continues to be mapped across a range of disciplines, arguably the scholar most closely associated with this academic practice in direct relation to the American public sphere, ${ }^{6}$ comparatist Peter Brooks, defines his task (in comparatively less orotund, Krausian tones) this way:

Many have assumed that I propound the notion that reading great books makes you a moral person (I don't); or, in a more nuanced variant, that I use great books as a vehicle for teaching the ethical life. But I am not a philosopher, and I don't deal in virtue or even morality in any direct way. What I mean by "the ethics of reading" is simpler, more basic, perhaps more

A related account of this model is outlined by (Day 2011).

In the 1980s, the phrase itself was most prominently associated with by J. Hillis Miller's deconstructionist (Miller 1986). Since then, it has been diversely interpreted, e.g., (Dagenais 1994; Rorty 1997; Attridge 2005; Gallup 2000; Deming 2008; Freed 2017; Moya 2015). Relevant bibliographies include (Antor 2012; Jiang 2015).

6 In a June 2019 Google search of the phrase "ethics of reading," four of the first seven results return Brooks's work. 
radical. I believe that careful, detailed, close analytic reading of texts of all sorts, rightly understood and practiced, can itself be an ethical activity. ${ }^{7}$

To demonstrate, Brooks turned to the "Torture Memos" released by the U.S. Department of Justice's Office of Legal Counsel on 1 August 2002, ${ }^{8}$ a document plainly non-literary in intent, style and form, but more relevantly for Brooks, a stunning display of interpretive bad-faith. ${ }^{9}$

The "torture memos" suggest the pernicious effect of unscrupulous reading, whatever its origin. Can we affirm - as I hope we can — that our practice and pedagogy of reading leads our students to a reflective engagement with those "reasons assignable": with the tough and supple work of language in representing the world and clarifying its moral dilemmas? ${ }^{10}$

Fusing moral corrective and performative practice, Brooks called upon the special training in fine-grained textual analysis known as "close reading,"11 which, while it may certainly resemble the lineaments of a "spiritual discipline" (Kraus) ${ }^{12}$ is, optimally speaking, "rightly understood and practiced" (Brooks) by those academicians qualified in the rigors of literary studies-more specifically, the explication of its various speech genres. Where Kraus speaks of "the highest degree of responsibility," Brooks proposes that "[ $t]$ he kind of reading I have described may lie at the very heart of professional responsibility. It makes us more skeptical and self-aware. It might prevent us from falling into the moral abyss of the Torture Memos." Less abstractly framed, this, presumably, is what is meant by "the sole thing that can be violated with impunity."

Still, the thesis is debatable. Brooks's documented fascination with the poetics of detective fiction notwithstanding, ${ }^{13}$ readers act as investigators (even for putative crime scenes) only up to a point; likewise, reading holds out abyssal possibilities in the very midst of the drive to explication. ${ }^{14}$ Alongside a host of books, articles, and review essays that have sought some rapprochement between the discourses of literature and philosophy for the past four decades or so, Brooks's own model has been directly engaged by philosophers (Charles Larmore, Judith Butler, Kwame Anthony Appiah), literary scholars (Jonathan Culler, Derek Attridge), and other disciplinary peers (Patricia Williams, Jonathan Lear) in a symposium that grew out of a graduate seminar he supervises, "The Ethics of Reading and the Cultures of Professionalism," published as the essay-volume The Humanities and Public Life.

Even apart from the question of presumptive definition, the area of inquiry itself exceeds the boundaries of a single methodological approach, with theory and method alike tied to variable criteria such as genre, literary tradition, and not least, the text(s) at issue. This author's own recent work, for example (growing out of an earlier focus on narrative ethics) ventures a rather different exploration

7 (Brooks 2017). Brooks first expatiated on the topic a decade ago in (Brooks 2008a, 2008b). He presented some of the same ideas as recently as 2018 in the lecture-presentation "The Chameleon Poet and the Ethics of Reading." The most sustained critique of Brooks's argument in the context of ethical criticism belongs to (Mcdonald 2010).

8 https://nsarchive2.gwu.edu//NSAEBB/NSAEBB127/02.08.01.pdf. Compare the more recent strained efforts to gloss the transcript of a July 25, 2019 phone call between the Presidents of the US and Ukraine.

9 (Brooks 2005).

10 https://www.chronicle.com/article/The-Ethics-of-Reading/20323.

11 Brooks himself prefers the qualifier "slow" to "close." Among a number of recent pieces on the subject, see (Love 2010; Dubois 2007; Lentricchia and Dubois 2003; Colás 2007).

12 On Krauss's "ethics of language," see (Perloff 2014), the essay by (Heller 1984), and (Stern 1966). If the Austrian satirist seems a surprising spokesperson here, I follow the precedent that specifically invokes him in connection with that enterprise, as the Krauss epigraph above appears at the end of Charles Larmore's "The Ethics of Reading" in (Brooks and Jewett 2014). The entire volume is reviewed in (Di Lio 2016).

13 (Brooks 1984).

14 A rejoinder to Brooks's argument by Peter Kerry Powers concludes, “While the ability to read closely and industriously and with technical proficiency may further the ends of people seeking to do good, it seems just as plausible that the ability to do so can serve the ends of those who seek to do ill. We accept that great artists may not be great people, and that their art may even serve both good and bad ends at the same time. Why should we believe differently about great readers?" (Powers 2008). 
of its terrain that conforms more to certain features of surface, than of close, reading. ${ }^{15}$ Centered around the event of tactility or embodiment, an ethics of reading from this vantage takes shape as "the-book-in-hand," denoting the embodied plane on which critic-reader and text (sacred or secular) come into palpable contact, where touch ramifies in manifold senses. For Brooks, though, "ethical activity" correlates primarily with disciplinary method. ${ }^{16}$

One contribution to The Humanities and Public Life that cuts athwart the forensic lineaments of close reading, however, is "The Call of Another's Words," by philosopher-psychoanalyst Jonathan Lear. ${ }^{17}$ "[I]n the tradition of the humanities," as he notes, Lear relates an exemplary story (narrative ethics transacted according to disciplinary custom), whose topical burden unpacks a twinned motif of vulnerability and contact: the singular circumstance, the affective exigency, of "being struck by the words of another" (110). He tells a story about a story: the postscript to a valedictory narrative by Plenty Coups, the last great chief of the Crow Nation (1848-1932), as recorded by his interlocutor Frank B. Linderman in his 1930 biography.

As the coda to a larger performative act of storytelling, Lear's anecdote expounds his essay's central argument, which centers on an ethic of "aesthetic receptivity" and the enactive reading practices it legitimates. Through a kind of transformative mimesis, Lear writes, "We need the poetic words of another to wake us up" (114), to draw us "out of ourselves and towards our own humanity and the humanity of others" (115). This is the lesson in affective exigency and narrative ethics he draws from his protagonist, who models for him something both deeply personalized and also culturally redemptive. Among other things, ethics, here, means the conjuring forth of "some kind of response" (110), in this case, the very book that Lear composes, which narrates a secondary witnessing to a prior act of witness-lodging a kind of hope, one could say, in a book about a book.

By way of introducing this special issue of essays on ethics and literary practice, I want to proceed in a somewhat similar fashion. My limited focus will be (literary) reading as ethical practice. If the philosophically superintended discourse of ethics can lay justifiable claim to "its singular capacity to adhere to, affiliate with, bury itself in, provoke, or dislodge other discourses,"18 then its actual work will always prove primarily discursive, whatever epistemological or deontological reasoning is brought to bear. Any potential hinge to literary practice, specifically, the task of criticism, would seem to express itself just there, as the very engine of altered reading-of reading as alteration.

What does such doubled character-the ethical-literary or literary-ethical-look like concretely? And how might one take up Cavell's pointed challenge for the critical project, which takes place as a staging of exemplarity within a series or history of intertextual promptings, reading underwritten by re-inscription? How might we embody Kraus's language-ethics? For an illustration, consider a rather different sort of anecdote than the one related by Lear: a richly prosaic lesson in reflexivity from a 1998 essay by the Israeli novelist David Grossman, in which ethical 'X-factor' ${ }^{\prime 19}$ meets mimetic X-ray through the random call of another's words:

One morning I got on a bus and sat down next to a fleshy older man with a red face. He gave me a doubtful look as if he were considering whether I was reliable enough to hear what he had to say. Then he said, with a quiet sigh, "nobody knows what the other guy keeps

15 (Newton 2015). "Surface reading" is outlined by Stephen Best and Sharon Marcus in their introduction to (Best and Marcus 2009). Compare also critic James Woods's characterization of criticism as sedulous redescription: "In [Virginia Woolf's] criticism, the language of metaphor becomes a way of speaking to fiction in its own accent, the only way of respecting fiction's indescribability ... . To describe literature critically is to describe it again, but as it were for the first time" (108-9). (Wood 2010).

16 For instance, (Cox 2015).

17 In the book Lear published a few years earlier on how a culture staves off and recovers from its own exhausted history, (Lear 2008), Lear renders this extremity as a temporal "breakdown in happenings" (6), to which an audience of virtual interlocutors is thus made witness.

18 (Harpham 1999).

19 (Harpham 1999). "Ethics, I argue throughout, realizes its full creative potentiality not in 'itself,' but as a kind of X-factor, a bracingly alien incitement to inquiry and discrimination (xiii)." 
inside." Before I had a chance to ask what he meant, he lifted up a brown envelope, drew out an X-ray, and held it up to the light. "That's me," he said with unrestrained pride. I took a careful look, but wasn't able to identify the picture with the person. "Those are my kidneys," he explained. "They're always making sand and stones." He lifted the picture higher so that other people could enjoy it, and explained his entire inner world to an interested crowd that had gathered around him. For a moment I was able to view the colorful crowds of Jaffa Street, Jerusalem's main street, through this man's inner organs. I saw high-school kids with earrings, a squad of soldiers gathered around two blond tourists, Hasidim in black coats, a procession of Japanese philo-Israeli cultists in clad in lemony yellow, two policemen frisking an Arab, a group of three-year old kids from a nearby heder running and shouting in the throng. That noisy swarm was visible through a single pair of kidneys! ${ }^{20}$

In the language of rabbinic midrash, the nimshal (referent) that corresponds to this story's mashal (exemplum), i.e., the essential point it is designed to illustrate, ${ }^{21}$ would be grounded in a particular Israeli penchant, says its author, for being "intimate with total strangers" (socially liberating at best, but also very possibly intrusive-chutzpah as cultural virtue.) In other words, it belongs to the rhetoric of exemplarity. ${ }^{22}$ To that extent, the anecdote does culturally representative work, whose rhetorical task literary critic Frank Lentricchia spells out this way: "stand[ing] in for a bigger story, a socially pivotal and cultural pervasive biography which it illuminates-in an anecdotal flash it reveals the essence of the larger unspoken story, and in that very moment becomes exegesis of a public text" (136). ${ }^{23}$

According to this view, Grossman's fable fulfills the anecdotalist's directive for "a social form which instigates cultural memory: the act of narrative renewal, the reinstatement of social cohesion" (137). And insofar as Grossman relates this story in the context of larger and more troubled reflections on Israel's fiftieth anniversary in 1998, it serves convincingly as cultural metonym. "Anecdotes," we're told again, "would appear by their very nature to depend on a stable outside narrative, given and known, but in fact-most dramatically in their written, high literary style, they work at critical turning points of cultural crisis" (137).

Could we call that operation, the work of cultural politics, "ethical?" Certainly, a case could be made, which, much like Brooks' critical method in concert with the particular prooftext he selects, highlights an almost inevitable reciprocity between the ethical and political as adjacent, often interpenetrating critical categories. Thus, in his own virtuosic demonstration of critical practice, ${ }^{24}$ Lentricchia scrutinizes Wallace Stevens' recondite lyric, "Anecdote of a Jar," detailing its relentless re-entanglement with politics, aesthetic ideology, national and social history. In the hands of a close reader by profession, anecdotes can assuredly mean that much.

As to Grossman's anecdotal exercise in descriptive panorama, we might confine ourselves first to the more restrictive labor of how its staging unfolds according to its local rhetorical elements: an especially artful play with metonymy and metaphor, the literary radiography, so to speak, of poetry and literary fiction. What are this text's particulars? How should a close reading attend to its narrative and figural surfaces as well as its perfectly apposite thematic burden: topographical surface in relation to (putatively occluded) depth?

In an ethically counter-reading spirit, we might begin by reading the text against itself. It commences with the casually inserted but crucial detail that the narrator, like many of his compatriots, rides the bus, the quintessentially demotic mode of transport, where chance rendezvous with otherness

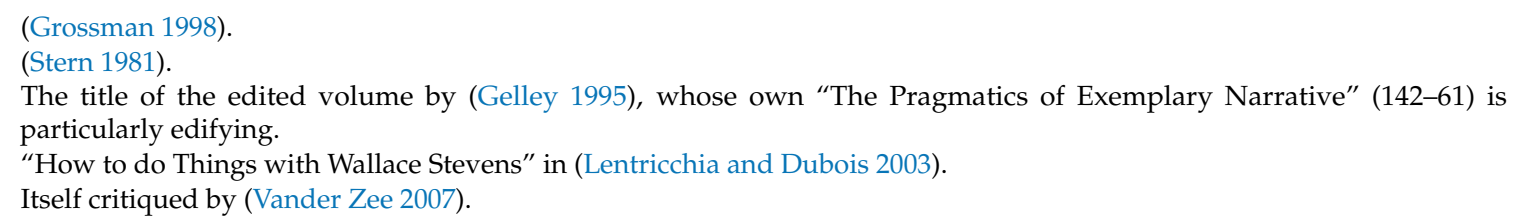


prevail as a matter of course. ${ }^{25}$ Tucked into and to be glimpsed among the climactic ensemble of disparate figures at the end-adjacent to tourists on one side and schoolboys on the other-are "two policemen frisking an Arab," a casual detail that signals a rather different social calculus entirely. Indeed, one could plausibly venture that it spoils the otherwise vivid pageant of passers-by enabled by a culturally representative bus ride and the casual radiolucent interposition of the human interior.

Is it intended to signify just another everyday occurrence on Jaffa Street? The detail startles, but only if we pause the list and consider it for a moment by itself: one more instance of color and swarm, and yet categorically different from all the others. Among other things, the Arab counts as the only element in an inventory of plural instances to be literally singled out, even relative to the two policemen who frisk him. From high-school kids to three-year old kids, a squad of soldiers to two policeman, blond tourists to Hasidim to Japanese, "the Arab" remains entirely singular-even if, syntactically speaking, the catalogue functions as an "open series," with each element grammatically identical to all the others. The X-ray itself is at once shadow and image, medium and picture, objectively neutral yet still enframing.

Yet, what does it mean to descry ever so briefly through it the enforcement of state power, as witnessed under the general auspices of the Ministry of Transportation? Does the act of frisking reward the tribute to Israelis' characteristic "intimacy with total strangers?" Or, by casually introducing a very specific category of stranger-in-our-midst, does it not also ever so slightly compromise that affirmation? Does it mean to, in fact-given an author justly famous for his principled stance on the Israeli left, a pained and conscientious observer of an occupation and its moral cost, whose fiction does not casually record such details. ${ }^{26}$

On all such questions, the anecdote at hand would seem to keep its own counsel; its implied exemplarity tracks accordingly. Like Jonathan Lear on his initial reaction to reading about Plenty Coups' decision to cut short his narrative from Linderman's afterword, that only much later began to haunt him as a figure for foreclosed history, I myself must confess to having missed the anomalous character of the detail upon initial readings-a cautionary lesson in any reader's accountability. ${ }^{27}$ It was only subsequently that the detail came alive for me, upon discovering "An Arab at Ben Gurion Airport" (2015) by Palestinian poet and civil engineer Marwan Makhoul:

I'm an Arab!

I shouted, at the doorway to departures,

short-cutting the woman soldier's path to me.

I went up to her and said: Interrogate me! But

quickly, if you don't mind. I don't want to miss

departure time.

...

The security guard hands me over to the police officer

who frisked me all of a sudden and called out:

What's that?

My national organ, I say.

and my progeny, the fold of my family and two dove's eggs

to hatch, male and female, from me and for me."2828(Makhoul 2007).

25 In this light, Grossman's prose-poem recalls the famous lyric by Israel's national poet Amichai (2003), “Mishlosha o arbaa baheder [Of Three Or Four In A Room], whose opening stanza reads, "Of three or four in the room/[There is] always one [who is] standing at the window./He must see the injustice amongst the thorns/And the fires (burning) on the hills./And how men who departed whole/Are brought back to their homes in the evening, like small change." (Amichai 2003).

26 For example, the profile in (Packer 2010) The New Yorker (27 September 2010) and the interview in (Cooper 2016).

27 The name means "many achievements." Lear's anecdote represents, so to speak, the photonegative to Grossman's insofar as its subject had to be reluctantly drawn out: "It is only when repeatedly pressed that Plenty Coups uttered these haunting words. As a psychoanalyst I am fascinated by speech that does not want to be spoken" (110). 
Yet, surely, to pose such questions, to disturb this story's aesthetic surface, to dialogize it, to make the straightforwardly grammatical agrammatic, is part of what its "ethical X-factor" must signify? As has been argued for the narrative act of self-accounting, transparency and opacity, openness and hiddenness, ethical success and failure will always nest inside each other in such instances of crosshatched revelation, which a related and especially apt formulation I admire renders as "the creative act of letting the other appear." 29

If we turn now to the specifics of narrative chronology, the fellow passenger's unprompted remark, "Nobody knows what the other guy keeps inside" serves as the motivating platitude that becomes, at first, literalized into object (kidney stones), and subsequently transposed into perceptual metaphor (X-ray). That sequence itself, the story's figural armature, narrates a signifying chain from banal to veridical to poetic truth. In parallel, the series of speech and gestural acts proceeds from dialogue to group exposition to personal epiphany. Synecdochally, person transposes into viscera while the vernacular metonymy itself ("sand and stones") displaces from interior (kidney) to exterior (limestone-faced Jaffa Street ${ }^{30}$ ) -the whole complex of inside/outside figuration prefigured by the drawing out of the radiograph from within its plain brown envelope, and perhaps even inversely, boarding the bus from without in the first place. (On the most literal level, we should also remember that, unlike the comic book version, $\mathrm{X}$-ray vision through radiographic shadows would permit a much-occluded view at best.)

As Stevens' "Anecdote of a Jar" allegorizes the very condition of literary form- "its resistance to formalist closure, [that] there is always something outside the text" (Lentricchia, 139)—so Grossman's anecdote teaches a prose lesson about the poetics of intimacy and publicity, and the stubborn fact that exteriority will have its due. Metonymy nests inside metaphor, the hidden becomes exposed, and transcendent, or at least transformative, vision becomes a matter of ethical accident or grace-not, significantly, without blemish. As readers glimpse the same colorful crowd and noisy swarm made visible through a single pair of kidneys—including that possibly truant detail—so the anecdote lends itself to an allegory of generous surface reading, repaying analytical scrutiny with a very particular kind of semiotic remainder. ${ }^{31}$ Significantly, all of this happens in plain textual sight.

That ethical shadow also signifies as political surplus merely underscores that the story is free to perform the full extent of its figural work. ${ }^{32}$ Its final exclamation point may add a self-celebrating touch. It does not, however, entirely absolve the cataloguing eye, with which, structurally, our own perspective must coincide. Shadows on the ethical belong as much to it as those it casts, which merely affirms the adhesive, affiliative, discourse-dislodging latency of its X-factor. The "careful look" Grossman's anecdote endorses-even if it does happen to chime adventitiously with the essential component of close reading-may well not guarantee an expected symmetry between person and identifying picture-image. But open-ended viewing, especially when refracted through a creatively choreographed literary device, is never entirely innocent anyway, since it can never wholly predict what will come into view. ${ }^{33}$

To complicate both Brooks and Grossman, then, a less "applied" or instrumentalist ethics of reading will also entail our exposure as readers, or as Stanley Cavell captured this dimension psychoanalytically, "that it is not, first of all the text that is subject to interpretation, but we in the gaze and hearing of the text." ${ }^{34}$ Whatever else such reorientation suggests, it positions us not primarily as sovereign reading

29 (François 2008). On narrative ethics in the first-person: (Butler 2005; Cavarero 2006).

30 Described in the section "Holy Stone" from (Mendel 2013).

31 As novelist China Miéville puts it, "Fiction is always more interesting when there's an evasive surplus and/or a specificity ... Allegories are always more interesting when they overspill their own levees." (Miéville 2010).

32 According to Best and Marcus, as "attentiveness to the artwork itself is a kind of freedom" so "reading becomes what [New Formalist critic Marjorie] Levinson calls 'learned submission' ... because in submitting to the artwork, we come to share its freedom" (14). A critique of this position is ventured by (Kaul 2013).

33 (Newton 1995).

34 "The Politics of Interpretation," (Cavell 1984). "[Turning the picture of interpreting the text into one of being interpreted by it" and the twin possibility that such a model of reading is "therapeutic or redemptive" is a significantly different argument 
subjects who project their understanding, but rather as being disclosed in front of the text, with our reading majesty gainfully alienated, ethically altered. ${ }^{35}$

This insight intersects with the more obviously political point about the lyric poem that calls itself an anecdote: it cannot seal off the exterior world. Extrapolated purely as method, an ethics of reading stands in need of some modification, for it conduces not merely to something we employ or construct, but also to an event that happens to us, an alteration we undergo. Reading troubles mastery even while providing an instrumental platform for it, just as ethics does not solve problems (says Harpham), it structures them. If Grossman's story allegorizes enlarged, or altered, vision, it also captures a peculiar pathos that underpins human sympathy in life and through reading. ${ }^{36}$

We constantly present to one another the image of a dissonance between what in the end we cannot avoid being —embodied, contextual, and turning toward the uncontextual-and what through chance, ambition, and failure we occasionally and apparently become. This incongruity between what we seem to be and to want, on the one hand, and what happens to us and what we make of ourselves, on the other, recounts the master tale of humanity. It summarizes all our other misadventures and accomplishments. ${ }^{37}$

"What happens to us and what we make of ourselves"- or more saliently here, of ourselves while reading-limns a horizon for the pathos of the ethical itself. It opens onto a critical terrain where reading practice becomes its own emergent Other, its $X$-factor subject to auto-generated $X$-ray: reading, in short, as othering. Beyond the efficacy of method, what ethical criticism ideally discloses is reading's Uncanny, ${ }^{38}$ the incongruity or stubborn remainder aslant fulness of knowledge and exercise of mastery. While literary reading may well aspire to the adventurous (a word, incidentally, that Levinas connects directly with the ethical ${ }^{39}$ ) and even disobedient ${ }^{40}$ it can also open a space for precarity and the unforeseen-for example, the call of another's words.

Our anecdote discloses such an (ethical) shadow at the outset: "He gave me a doubtful look as if he were considering whether I was reliable enough to hear what he had to say." Whether or not what "he had to say" offers the most useful guarantee of moral gain, and notwithstanding the redemptive bewilderment ${ }^{41}$ it promises_- "That noisy swarm was visible through a single pair of kidneys!"- - the claims of scrutiny remain intact. As an ethics of practice, then, such sensibility, resourcefully cultivated, attests to the intuition that we participate in, are made answerable to, a circuit of transferential promptings generated by and through the act of reading. Like so many shadowgraphs, opaque

from the aesthetic propounded by Elaine Scarry's “Poetry, Injury, and the Ethics of Reading" in (Brooks and Jewett 2014) and also (Scarry 2012).

35 (Ricoeur 1998; Robbins 1999). See also the important discussion of narrative ethics in relation to "the possible" by (Meretoja 2018).

36 An intricate tutorial in narrative ethics (and Jewish humor), Grossman's 2014 novel A Horse Walks Into A Bar satirically restages this same principle, i.e.,- "How, in such a short time, did he manage to turn the audience, even me to some extent, into household members of his soul? And into its hostages" (57) (Grossman 2017)? Its plot features a stand-up comedian, grotesquely self-exposed, holding forth before a diversely assembled crowd, painstakingly witnessed by a spectator-narrator in the throes of his own self-accounting.

37 (Unger 1984). Philosopher, social and legal theorist Roberto Mangabeira Unger's non-literary take on sympathy distinguishes it from a conventional argument for empathy in reading, as critically appraised by Namwali Serpel in (Serpel 2019).

38 (Hoffman 2001). "In reading, understood as an archaeology of the text, one digs into terrain that is not manifestly one's own and yet in which one has a personal stake. Why read, then? In order to not know, I want to say, in order to preserve the trace of experience, unknown, within oneself. The shock of recognition one experiences in reading does not require full acknowledgment; its incompleteness is guaranteed by the very otherness of the text." (75-76).

39 "Substitution," in (Levinas 1996, 1981).

40 (Blackler 2007). Readers disobey their own fixedness in pursuit of the adventure, the vagrancy or "vagabondage" of reading (xiv). In demurral of that central thesis, however, one of this book's reviewer remarks that its "positing of 'the Sebaldian reader' seems to be far less a celebration of disobedience than of an ideal reading practice carried out by highly literate and astute readers who have at long last found an object suitable to their intellectual capabilities." See also the review by (Schmidt 2008).

41 Compare Geoffrey Hartman's claim in (Hartman 1980). Given "the seductive boast of every book, [that] we are tempted to enter an unknown or forbidden realm" (20), the ideal critical posture locates us as "charmed and bewildered readers, who feel that hermeneutic hesitation is the essential quality of philosophic art" (38). 
windows onto altered selves, acts of literature ambiguously hold us as much as we-belated and decentered readers that we are-hold them.

Beyond these local questions for an ethics of reading, this special issue of Humanities in "Ethics and Literary Practice" was designed to invite an array of interventions, approaches, and foci, and the contributions summarized below realize that purpose to edifying effect, with attention to philosophy, politics, postcolonialist and feminist theory, genre, religious discourse, and literary practice, as multiple instances of analytic (or performative) convergence: more succinctly put, ethics and its Others.

Two cull from the formative synthesis of philosophical and literary thinking practiced for six decades by the late Stanley Cavell: Richard Deming's "Senses of Echo Lake: Michael Palmer, Stanley Cavell, and the Moods of an American Philosophical Tradition" and Mette Blok's "Endlessly Responsible: Ethics as First Philosophy in Stanley Cavell's Invocation of Literature." Where the one puts the philosopher in direct conversation with a contemporary poet, the other sketches a dialogue between Cavell and continental philosopher Emmanuel Levinas.

In seeking to "bring the weight of philosophy and its concerns to bear in the practice of reading poetry," Deming reads Cavell's long-evolving consideration of Emerson and Thoreau as the progenitors of a distinctly American philosophical tradition by way of his former student, poet Michael Palmer. As Cavell's Emerson proposes nor just a new form of philosophy but also "a reform of the possibilities of philosophy, of how we might imagine philosophy might act and sound," so for Deming, Palmer's Notes for Echo Lake "locates itself, its language, and the way we might be called to read it in a series of echoes and locations." And as Cavell had already modeled for Thoreau, as well—Deming underscores the proximity in time and space of Notes for Echo Lake and the expanded edition of Senses of Walden, both having been published in the same year (1981) and through the same press (North Point) - so in Palmer's poems, "the acknowledgement of one's own subjectivity becomes the means by which others-by comparison, through contrast—can come to recognize their own," the point of convergence and even overlap between the sometimes co-implicated practices of philosophy and poetry.

Mette Blok's essay was composed in the aftermath of Cavell's passing in 2018. Starting from the premise that "that the theme 'ethics and literature' in Cavell requires an investigation of the concepts skepticism, romanticism, and moral perfectionism and their internal relations," Blok argues that "they gr[o]w out of each other, not only chronologically but also logically, and that romanticism is what binds skepticism and moral perfectionism together: Romanticist texts are both the expression of and the potential recovery from skepticism, thus making possible the achievement of moral perfectionism." All three concepts comprise a singular ethical standpoint (or theory), constellated through Cavell's wholly individualized voice, which takes shape through the specifically literary particulars that he gleans.

Not by accident, those texts Cavell assembles as instances of perfectionist sensibility, for example, Kleist's The Marquise of $O$ and Ibsen's A Doll's House, in league with his idiosyncratic readings of Emerson and Thoreau, exemplify, for Blok, the work of Bildung: "they are all in one way or another edifying; there is some story of education, cultivation or transformation of the protagonist or of his or her society for the better." The essay's concluding section, "Levinas or Emerson?" places Cavell midway between two contrastive versions of philosophical practice and the ethical-literary/literary-ethical, with each intellectual figure being brought to bear on the essay's valedictory insight, that "skepticism or tragedy is only half of our lives, and not the most important one ... [;] the other half is romance."

Three contributions-Josephine Donovan's "Ethical Mimesis and Emergence Aesthetics," "Interlocutors, Nonhuman Actors, and the Ethics of Literary Signification" by Donald Wehrs, and Thomas Claviez's "Neorealism, Contingency, and the Linguistic Turn"- track the convergence of ethics and literary practice with reference to large-scale theoretical paradigms. From the physical sciences, Donovan retools emergence theory towards an emergence aesthetics, "the idea that something qualitatively new sometimes spontaneously emerges when a constellation of isolated heterogeneous materials combines into a new whole or system." In the service of what he calls an "ethics of contingency," Claviez takes a poststructuralist approach to both the metaphor/metonym bifold (Roman Jakobson's 
1953 essay "Two Aspects of Language and Two Types of Aphasic Disturbances" as complicated by Paul de Man's "Semiology and Rhetoric" from 1973), and contemporary philosophies of recognition. Wehrs makes a case for a theory of literary autonomy whereby texts act as quasi-interlocutors in a Levinasian sense.

Taking her cue from emergence theory as formulated in the sciences, Donovan begins with the claim, previously elaborated in her 2016 book, The Aesthetics of Care, that the nexus of mimetic art, its production, and its reception, embodies a "transfigurative resurrectory process." Appealing to a range of theoretical perspectives including Theodor Adorno's concept of "mimetic comportment," Hubert Zapf's literary ecology, and Laurence Buell's eco-aesthetics, Donovan provisionally models the application of emergence aesthetic theory with reference to Richard Powers's 2018 novel, The Overstory.

Donald Wehrs's paper proposes a model for how "ethics and literary practices may intersect in ways that allow one to attribute an autonomous signifying agency to literary discourse without lapsing into decontextualized aestheticism or neoliberal conceptions of subjectivity." Marshalling figures such as Levinas, Derek Attridge, Rita Felski, and Bruno Latour, Wehrs addresses the nonhuman and ambassadorial agency of literary practices, and more particularly for an ethics of reading, "literary signification's irruptive reformative potency." The literary examples project a deliberate sweep: in the spirit of Erich Auerbach, two scenes of anagnorisis from antiquity, Telemachus' intimation of divinity (Odyssey 1: 319-24) and Judah's encounter with Tamar (Gen. 38); and from the discursive world of the modern novel, two moments from Jane Austen's Sense and Sensibility (1811) and Chimamanda Ngozi Adichie's Americanah (2013).

Claviez's article follows upon his earlier work on critical theory and literary history with the more immediate aim of pinpointing "the ethical stakes" in metonymy as a representational device. Beginning with the Aristotelian problematic of historical contingency rendered through the formal of machinery of narrative poetics, and elaborating a distinction between two categories of contingency, "epistemological" and "representational," the argument concentrates on a specific literary movement (neorealism) and topos (the intersubjective drama of recognition). "For centuries," Claviez argues, "we have been telling ourselves the story of human development as a story of the succession of allegedly ever more successful strategies to overcome contingency; usually along the lines of Myth, Monotheism, and syllogistic Reason." In reviewing what has come to be known as "the philosophy of recognition" (Jürgen Habermas, Axel Honneth and Nancy Fraser), Claviez looks to Jonathan Franzen's 2010 novel Freedom (cited by Honneth) and Dave Eggers's Circles (2013) as his literary examples, allowing the strong possibility that to "induce us to take a different stance towards contingency might be part and parcel of the project of Neorealism."

Two essays anchor themselves with regard to discourses of (post)colonialism, Hille Haker's "Towards a Decolonial Narrative Ethics" and Jay Rajiva's "The Answer is Paracritical: Caribbean Literature and The Limits of Critique." Haker enlists Kafka's short fiction "A Report to the Academy" and Uwe Timm's 1978 historical novel Morenga as a platform for tracing both the limits and the obligations of intercultural understanding overseen by structures of colonialism. In contriving her own rapprochement between history and literary practice, Haker cites Paul Ricœur's model of the "crossed reference" of empirical and narrative truth and his differential analysis of reciprocity and mutuality. The essay's core concern centers on the problematics of recognition, its misfires or incompletions as well as its exemplary conditions.

Apropos the reception of Rita Felski's The Limits of Critique (2015), conducted (much like the book itself), almost entirely within the ambit of an Anglo-American literary tradition, Rajiva wonders pointedly, "Why does the postcritical "turn," which urges scholars to abandon the detachment and suspicion of critique in favor of affect, sympathy, and enjoyment, seem to be unaware of the blindspots of its own literary-cultural lineage?" Towards an answer, he looks to an African-American and Afro-Caribbean corpus of texts that "predate and complicate the critical-postcritical binary." Triangulating Philosopher-poet Édouard Glissant's Poetics of Relation on the origins of Creole speech, writer-critic Nathaniel Mackey's collection of essays and interviews, Paracritical Hinge, 
and Trinidadian-Canadian author Dionne Brand's 2005 novel What We All Long For, Rajiva wishes us to interrogate not only the cultural implications of the reading "postures" we ordinarily assume but also the kinds of texts we take to be paradigmatic. From Mackey, he borrows and elaborates the concept of paracritical hinge, which extends Mackey's earlier investment in collaborative/discrepant encounters into further realms of expressive contingency: "paracriticism functions as a type of traffic, a vibrant mix marked by tenuousness and risk, the outpouring of improvisation as literary creativity," an interpretively contrapuntal move Rajiva also calls "reading for the blue notes."

Two contributions, Andreea Deciu Ritivoi's "Reading (with) Hannah Arendt: A Literary Ethics for a Politics of Belonging" and "The Fallacy of Analogy and the Risk of Moral Pretension: Israeli Literature and the Palestinian Other" by Adia Mendelson-Maoz, situate their analyses on a critical fault line. Mendelson-Maoz asks the politically- as much as ethically-inflected question, "Can Israeli literature find different venues to discuss the Palestinian catastrophe without drawing on analogies to catastrophes experienced by Jews?" Her essay contrasts two instances in modern Hebrew fiction where the logic of analogy appears to undermine or even neutralize narrative-ethical possibilities, S. Yizhar's short story "Hirbet Hiz'a" (1949), Amos Oz's autobiographical novel Sipur al ahava ve-hoshekh [A Tale of Love and Darkness] (2005), with two instances of a novelistic counter-tradition by the late Ronit Matalon foregrounding the experiences of Israel's Mizrahi population, Sarah, Sarah [Bliss] (2002) and Kol tse'adenu [The Sound of Our Steps] (2015).

For Ritivoi, the political subjectivity of the displaced person, doubly inscribed by immigration discourse and humanitarianism but also narrativized by statelessness and "bare life," transposes into literary space as the ethical object of compassion and pity. "To articulate an ethics of alterity from the perspective of the refugee," she writes, "is to be concerned with the ways in which difference gets erased rather than embraced." Toward that end, she appeals to Hannah Arendt, specifically the essay "We Refugees" (1943), the critique of Stefan Zweig's assimilationist allegiance to Bildung in The Crisis in Culture (1961), and writings collected in Reflections on Literature and Culture (2007). Moving to Arendt's reading of Melville's Billy Budd, Sailor in On Revolution (1963), Ritivoi asks, "what are the implications of an implicit or explicit ethics of literature for broader political visions and philosophical insights that claim to originate from literary configurations?" The essay concludes with a brief reading of the novella "Rock Crystal" by Austrian writer Adalbert Stifter (alongside Brecht, Broch, Kafka, and Zweig, a revered author for Arendt), which prompts this concluding gesture: "If the state claims the individual already at birth and identifies us as either citizens or alien, engaging with another's standpoint through aesthetic representations gives us a chance to begin anew, to 'read ... (stories and poems) as though nobody had ever read them before'."

Eugene O'Brien's "'A Pause for Po-Ethics': Seamus Heaney and the Ethics of Aesthetics elaborates on the late Irish poet's own neologism, which, in establishing a discursive conjunction for the discourses of poetry—as a form of epistemology—and moral agency "allows for a slanted perspective, a swerve, which will look at the ethical demands on life from just such a different perspective." Following Levinas and Derrida, O'Brien traces the ethical component of Heaney's poetics as "a form of redress against the instrumentality of the contemporary world." Drawing from classical texts by Shakespeare, Dante, and Homer as well as modern authors like Bishop, Hopkins, Miłosz, Levi, and Camus, the essay's particular virtue lies with its careful attention to the Heaney's concept of "po-ethics," distributed among a number of his own essays but which has not figured prominently in the critical literature to date.

Michelle Boulous Walker's and Cynthia Wallace's papers explore parallel feminist approaches to a literary ethics of attention: the former, building on psychoanalytic theorist Teresa Brennan's The Transmission of Affect, and the latter, with specific regard to Simone Weil and the religious question. In "Porosity: Ethics and Literature Between Teresa Brennan and Hélène Cixous," Walker looks at energetic transfer across intersubjective boundaries, affective pathways rooted in "the intelligence of the flesh," dramatizing the way "the body is implicated in its own thinking." Following Brennan, Walker connects such embodied transmission, the "paradoxical detaching and embracing of affect," to 
the work of philosophy, whose practice, she argues, "reunites us with what we might call attentive discernment," pointing the way in turn to "the need for personal and political transformation." In her conclusion, Walker invokes Cixous's concept of the entredeux, the interspace where ethical and literary energies meet and a discursive site of "play between destructive force and regenerative openness."

As its title indicates, Cynthia Wallace's "Attention, Representation, and Unsettlement in Katherena Vermette's The Break, or, Teaching and (Re)learning the Ethics of Reading" explores the specifically pedagogical dimension of an "ethics of literary attention." Interpretive practices that grow out of such an ethics, Wallace suggests, "can help us resist the blend of hyperattention and attention deficit that grows out of the current digital economy." Beginning with an initial analysis of Vermette's novel and pivoting to a discussion about the current state of literary-ethical theory, Wallace writes, "while I have been arguing that The Break has a great deal to teach scholars about the New Ethical Criticism, the New Ethical Criticism may not have quite so much to teach us about The Break," a claim that implicitly hearkens back to Brooks, Lear, and the question of method, and also invokes the figure of Emmanuel Levinas. As to the specific literary text on which her essay focuses, Wallace entertains the crucial proposition that "which texts we bring into our theorizing of literary ethics makes all the difference in the world." Thus, Vermette is a Métis writer from Treaty One territory in Canada; and The Break begins, provocatively, with a rape. Relying on justifications both pedagogical and theoretical, an ethics of attention, of literary witnessing, in Wallace's view, "means returning to the humbling space of non-mastery" - with obvious relevance for the thesis already propounded here.

In "To Read Matthew's Gospel After Auschwitz is Barbaric,"-an essay from the special issue not included in this e-book-Gary Phillips focuses on the conundrum of a world-historical religious text that also "excels as a script of violence that implicates not only antisemitic fanatics but even the Christian faithful." To that degree, Matthew's Gospel challenges not only general readers (and believers) but also biblical scholars "who face a heightened ethical accountability for the material effects of their readings and to take responsibility for the ongoing barbarism directed against the suffering innocent." Using Adorno's famous hyperbole as its point of departure, as refracted through both the Matthean narrative and paintings by Holocaust survivor Samuel Bak, Phillips reflects on the ethical contradictions of "the barbaric beauty of aesthetics and analysis under the sign of Auschwitz."

Finally, from Steven B. Katz, we include two pieces: an essay on ethics, language, and time, and a lyric sequence, "The Ghost of Objects: A Villanelle for the End of the Anthropocene" and "Time, Proust, Being, You," underscoring the link between ethics and literary practice. The two poems probe the question of human time in a framework drawn from Heidegger and Levinas, triangulating the dimensions of prosody, temporality, and ethics. Where the first-an experiment in the tightly structured Renaissance French verse form known as the villanelle—asks, "can objects survive physicality?" the second laments that "Time does not heal ... but kills itself, and dies in us, so oblivious, and Other." In tandem, the sequence "examines the nature of time in relation to the end of the human-the death of the species in the Anthropocene, and the death individual personally-and speculates on what might come in the rhetorical-after that we can never know except poetically."

"Sonic Rhetorics as Ethical Action: Hidden Temporalities of Sound in Language(s)" examines what Katz calls "hidden sonic dimensions of time and ethics in language," as briefly exemplified by poetic, classical Greek, and Biblical Hebrew texts. In parallel with certain, "unconcealed" temporal dimensions on display in prosody and etymology, the essay seeks to explore a "sonic rhetoric in which language is not only a manifestation of time but the cause and content of it, a rhetoric in which time is already a moral reality, and the material world a shadow of signifiers, signs."

In conclusion and along with the editorial staff of Humanities, I commend the diverse group of contributors who brought such multifarious perspectives to a topic that feels only more urgent as 
language, meaning, and expression experience their own public and civic drama of transparency and occlusion in a monitory age of "post-truth." 42

\section{Contributors}

Mette Blok lectures in the departments of Communication and Arts and Aesthetic Culture at Roskilde University. Her publications include "Literature as Ethics: Stanley Cavell, Robert Musil, and the Scope of Moral Perfectionism" (Res Cogitans, 2018) and "Robert Musil's Literary Ethics: The Man without Qualities Reconsidered" (New German Review, 2014).

Thomas Claviez is Professor for Literary Theory and Director of the Center for Cultural Studies (CCS) at the University of Berne. His publications comprise books and essays on Environmentalism, Aesthetics, American Philosophy, Native American and African American Literature, American Studies, Otherness and Ethics, and, most recently, Theories of Community. He is the author of Grenzfälle: Mythos-Ideologie-American Studies (Wissenschaftlicher Verlag Trier, 1998) and Aesthetics \& Ethics: Moral Imagination from Aristotle to Levinas and from Uncle Tom's Cabin to House Made of Dawn (Universitätsverlag Winter, 2008) and the co-author, with Dietmar Wetzel, of Zur Aktualität von Jacques Rancière: Einleitung in sein Werk (Springer VS, 2016). He is also the editor of The Common Growl (Fordham, 2016) and The Conditions of Hospitality: Ethics, Politics, and Aesthetics on the Threshold of the Possible (Fordham, 2015).

Richard Deming teaches at Yale University, where he is Lecturer in English and Director of Creative Writing. He is a poet, art critic, and theorist, whose work explores the intersections of poetry, philosophy, and visual culture. His collection of poems, Let's Not Call It Consequence (Shearsman, 2008), received the 2009 Norma Farber Award from the Poetry Society of America. His most recent book of poems, Day for Night, appeared in 2016. He is also the author of Listening on All Sides: Toward an Emersonian Ethics of Reading (Stanford, 2008), and Art of the Ordinary: the Everyday Domain of Art, Film, Literature, and Philosophy (Cornell, 2018). Winner of the Berlin Prize, he was the Spring 2012 John P. Birkelund Fellow of the American Academy in Berlin.

Josephine Donovan is Professor Emerita of English in the Department of English at the University of Maine, Orono. Her research and expertise have covered feminist theory, feminist criticism, animal ethics, and both early modern and 19th-century American women's literature. She is the author of nine books of nonfiction and the editor of five. Her most recent books include The Aesthetics of Care: On the Literary Treatment of Animals (Bloomsbury, 2016) and The Feminist Care Tradition in Animal Ethics, co-edited with Carol J. Adams (Columbia, 2007). Feminist Theory: The Intellectual Traditions, first published in 1985, is now in its fourth edition (Continuum, 2012).

Hille Haker is the Richard McCormick, S. J., Chair of Moral Theology at Loyola University Chicago. She earned her doctorate (1997) and habilitation (2001) at the University of Tübingen, where her dissertation- "Moralische Identität: Literarische Lebensgeschichten als Medium ethischer Reflexion" ("Moral Identity: Literary Life Stories as a Medium of Ethical Reflection")—was awarded the dissertation prize in Catholic Theology in 1998. Her research interests include meta-ethics, normative ethics and hermeneutical/experiential ethics, social and political ethics, bioethics, feminist ethics, and aesthetics. She has edited the Values in Bioethics (Brill) series since 2017, and is the author, most recently, of Recognition and Responsibility: Critical Theory and Christian Ethics and Renewal of Catholic Social Ethics: Towards A Critical Political Ethics (Herder, 2019) and, with Molly Greening, co-edited Unaccompanied Migrant Children: Social, Legal and Ethical Perspectives (Lexington, 2019).

Steven B. Katz is Pearce Professor Emeritus of Professional Communication, and Professor Emeritus of English at Clemson University. His scholarly interests range from ethics in technical communication to the nexus of rhetoric, poetry, and science. His research foci include rhetorical analyses of ideologies of new technologies; conventions and ethics of styles in biotech and medical

42 I dedicate the introduction to my באֵֵליבט זון, Emmanuel Josiah, tender to my loco., heard clamoring for his die-cast toy

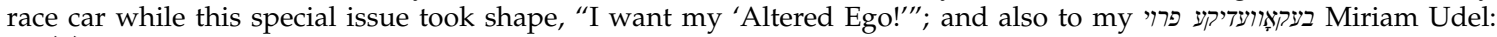

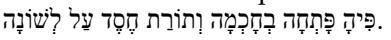


communication with the public; and the materialities and uses of language in different forms of writing, in religion, and in electronic media. His books include 9/11: Terministic Screens, Rhetoric, and Event, with Emily Ligon (Parlor Press, forthcoming), Nana! (poems) (Moses, Ink, 2005), and The Epistemic Music of Rhetoric: Toward the Temporal Dimension of Affect in Reader Response and Writing (Southern Illinois, 1996).

Adia Mendelson-Maoz is Associate Professor in Israeli literature and culture at the Open University of Israel. She investigates the multifaceted relationships between literature, ethics, politics, and culture, mainly in the context of Hebrew Literature and Israeli culture, specifically the literature of minority groups in Israel, questions of space and ethics in contemporary Israeli literature, and the work of novelist Yoram Kaniuk. Her books include Borders, Territories and Ethics-Hebrew Literature in Shadow of the Intifada (Purdue, 2018), Multiculturalism in Israel: Literary Perspectives (Purdue, 2014), and Literature as a Moral Laboratory: Reading Selected 20th Century Hebrew Prose (Bar Ilan, 2009. [Hebrew])

Eugene O'Brien is Senior Lecturer and Head of the Department of English Language and Literature at Mary Immaculate College. He is also the editor for the Oxford University Press Online Bibliography project in literary theory. His research interests include the poetry of Seamus Heaney; Irish culture and writing; literary and cultural theory. His recent publications include Seamus Heaney as Aesthetic Thinker: A Study of the Prose (Syracuse, 2016), The Soul Exceeds its Circumstances: The Later Poetry of Seamus Heaney (Notre Dame, 2016), Representations of Loss in Irish Literature, with Deirdre Flynn) (Palgrave Macmillan, 2018), and Tracing the Cultural Legacy of Irish Catholicism: From Galway to Cloyne, and Beyond, with Eamon Maher (Manchester, 2018).

Jay Rajiva is Assistant Professor at Georgia State University. His research interests include Global Anglophone and Postcolonial Literature, and Trauma Theory, focusing on South Asian and pan-African literature. His book, Postcolonial Parabola: Literature, Tactility, and the Ethics of Representing Trauma (Bloomsbury, 2017), analyzes literature of partition and civil war on the Indian subcontinent alongside apartheid and post-apartheid South African fiction. His next book project examines the relationship between animism and trauma in contemporary literature of India and Nigeria.

Andreea Deciu Ritivoi is Professor of English and Department Head at Carnegie Mellon University. Her research interests include rhetorical theory and Continental philosophy, narrative and identity, exile and transnationalism, Eastern European societies, and controversy. She is the author of Yesterday's Self: Nostalgia and the Construction of Personal Identity (Rowman and Littlefield, 2002) and Paul Ricoeur: Tradition and Innovation in Rhetorical Theory (SUNY, 2006), and the editor of Interpretation and Its Objects: Studies in the Philosophy of Michael Krausz (Rodopi 2004) and (with Richard Howells and Judith Schachter) of Outrage! Art, Controversy, and Society (Palgrave MacMillan 2012).

Michelle Boulous Walker is Associate Professor at the University of Queensland. Her research interests span the fields of European philosophy, aesthetics, ethics, and feminist philosophy. Her current research engages with the work of Emmanuel Levinas, Theodore W. Adorno, Luce Irigraray, Michèle Le Doeuff, and others; a new project focuses on questions of philosophy and laughter. Her books include Slow Philosophy: Reading Against the Institution (Bloomsbury, 2017) and Philosophy and the Maternal Body: Reading Silence (Routledge, 1998).

Cynthia Wallace is Assistant Professor at St. Thomas More College, University of Saskatchewan, teaching and researching in the areas of religion and literature, postcolonial literature, women writers, and literary ethics. Her current research explores embodied suffering and the prevalence of attention as an ethical ideal among women writing in the twentieth and twenty-first centuries, especially against a backdrop of attention deficits and surpluses, and the surprising influence of philosopher-mystic Simone Weil. Her book, Of Women Borne: A Literary Ethics of Suffering was published by Columbia University Press in 2016.

Donald Wehrs is Hargis Professor of English Literature at Auburn University. He specializes in novel genre and history, British eighteenth-century studies, literary theory, postcolonial studies, and comparative literature. His books include the Palgrave Handbook of Affect Studies and Textual Criticism, co-edited with Thomas Blake (Palgrave Macmillan, 2017), Cognition, Literature, and History, 
co-edited with Mark J. Bruhn (Routledge, 2014), Levinas and Twentieth-Century Literature: Ethical Trauma and the Reconstitution of Subjectivity (Delaware, 2013), and Levinas and Nineteenth-Century Literature: Ethics and Otherness from Romanticism through Realism, co-edited with David P. Haney (Delaware, 2009).

\section{About the Special Issue Editor}

Now Emeritus, Adam Zachary Newton was University Professor, Chair of the English Department, and Stanton Chair in Literature and Humanities at Yeshiva University from 2007 to 2014. Prior to that, he held appointments at the University of Texas at Austin in English, Comparative Literature, Middle Eastern Languages and Cultures, and Jewish Studies as the Jane and Roland Blumberg Centennial Professor. More recently, he has held appointments as Distinguished Visiting Professor at Emory University and Agnes Scott College. A cross-disciplinary scholar, he has written and taught at the boundaries of three knowledge practices: literary studies, philosophy, and religion. Alongside essays in a range of fields, he is the author of six monographs: Jewish Studies as Counterlife: A Report to the Academy (Fordham, 2019); To Make the Hands Impure: Art, Ethical Adventure, the Difficult and the Holy (Fordham, 2014); The Elsewhere: On Belonging at a Near Distance: Reading Literary Memoir from East-Central Europe and the Levant (Wisconsin, 2005); The Fence and the Neighbor: Emmanuel Levinas, Yeshayahu Leibowtz, and Israel Among the Nations (SUNY, 2001); Facing Black and Jew: Literature as Public Space in 20th-Century America (Cambridge, 1998); and his award-winning first book, Narrative Ethics (Harvard, 1995), which first formalized the term for a developing sub-field.

Funding: This research received no external funding.

Conflicts of Interest: The author declares no conflict of interest.

\section{References}

Amichai, Yehudah. 2003. Mishlosha o arbaa baheder [Of Three Or Four In A Room]. In The Modern Hebrew Poem Itself. Edited by Stanley Burnshaw, Susan Glassman, T. Carmi, Ezra Spicehandler and Ariel Hirschfeld. Translated by Robert Friend with commentary. Wayne State: Wayne State University Press, pp. 166-67.

Antor, Heinz. 2012. Literary Ethics. In English and American Studies: Theory and Practice. Edited by Martin Middeke, Christina Wald and Hubert Zapf. Berlin: Springer, pp. 243-47.

Attridge, Derek. 2005. J. M. Coetzee and the Ethics of Reading: Literature in the Event. Chicago: University of Chicago Press.

Best, Stephen, and Sharon Marcus. 2009. The Way We Read Now. Representations 108: 1-21. [CrossRef]

Blackler, Deane. 2007. Reading W. G. Sebald: Adventure and Disobedience. Rochester: Camden House.

Brooks, Peter. 1984. Reading for the Plot: Design and Intention in Narrative. Knopf: Oxford University Press.

Brooks, Peter. 2005. The Plain Meaning of Torture? Literary Deconstruction and the Bush Administration's Legal Reasoning. Slate Magazine. February 9. Available online: https://slate.com/news-and-politics/2005/02/theplain-meaning-of-torture.html (accessed on 3 February 2020).

Brooks, Peter. 2008a. The Ethics of Reading. The Chronicle of Higher Education, February 8.

Brooks, Peter. 2008b. The Humanities as an Export Commodity. Profession 2008: 33-39. [CrossRef]

Brooks, Peter. 2017. An Ethics of Reading? Washington, DC: Association of American Colleges \& Universities. Available online: www.aacu.org/diversitydemocracy/2017/winter/brooks (accessed on 3 February 2020).

Brooks, Peter, and Hillaty Jewett, eds. 2014. The Humanities and Public Life. New York: Fordham University Press. Butler, Judith. 2005. Giving an Account of Oneself. New York: Fordham University Press.

Cavarero, Adriana. 2006. Relating Narratives: Storytelling and Selfhood. Translated by Paul A. Kottman. Abingdon: Routledge.

Cavell, Stanley. 1977. The Senses of Walden: An Expanded Edition. New York: North Point Press.

Cavell, Stanley. 1984. Themes Out of School: Effects and Causes. Chicago: University of Chicago Press.

Colás, Santiago. 2007. Toward an Ethics of Close Reading in the Age of Neo-Liberalism. The New Centennial Review 7: 171-211. [CrossRef]

Cooper, Marilyn. 2016. David Grossman: The Dissenting Patriot. Moment. May 24. Available online: https://momentmag.com/david-grossman-dissenting-patriot/ (accessed on 3 February 2020). 
Cox, Sandra. 2015. An Ethics of Reading: Interpretative Strategies for Contemporary Multicultural American Literature. Cambridge: Cambridge Scholars Publishing.

Dagenais, John. 1994. The Ethics of Reading in Manuscript Culture: Glossing the Libro de buen amor. Princeton: Princeton University Press.

Day, William. 2011. A Soteriology of Reading: Cavell's Excerpts from Memory. In Stanley Cavell: Philosophy, Literature and Criticism. Edited by James Loxley and Andrew Taylor. Manchester: Manchester University Press, pp. 76-91.

Deming, Richard. 2008. Listening on All Sides: Toward an Emersonian Ethics of Reading. Stanford: Stanford University Press.

Di Lio, Jeffrey R. 2016. Review of Peter Brooks, ed. with Hilary Jewett, The Humanities and Public Life. The Comparatist 40: 352-59. [CrossRef]

Dubois, Andrew. 2007. Ethics, Critics, Close Reading. University of Toronto Quarterly 76: 926-36. [CrossRef]

François, Anne-Lise. 2008. Open Secrets: The Literature of Uncounted Experience. Stanford: Stanford University Press.

Freed, Joanne Lipson. 2017. Haunting Encounters: The Ethics of Reading across Boundaries of Difference. Ithaca: Cornell University Press.

Gallup, Jane. 2000. The Ethics of Reading: Close Encounters. Journal of Curriculum Theorizing 16: 7-17.

Gelley, Alexander, ed. 1995. Unruly Examples: On the Rhetoric of Exemplarity. Stanford: Stanford University Press.

Grossman, David. 1998. Fifty is a Dangerous Age. The New Yorker. April 20, pp. 55-59. Available online: https://www.newyorker.com/magazine/1998/04/20/fifty-is-a-dangerous-age (accessed on 3 February 2020).

Grossman, David. 2017. Sus ehad nikhnas le-bar [A Horse Walks Into A Bar]. Translated by Jessica Cohen. New York: Knopf.

Harpham, Geoffrey Galt. 1999. Shadows of Ethics: Criticism and the Just Society. Durham: Duke University Press.

Hartman, Geoffrey H. 1980. Criticism in the Wilderness: The Study of Literature Today. New Haven: Yale University Press.

Heller, Eric. 1984. In the Age of Prose: Literary and Philosophical Essays. Cambridge: Cambridge University Press, pp. 87-104.

Hoffman, Anne Golomb. 2001. Topographies of Reading: Agnon through Benjamin. Prooftexts 21: 71-89. [CrossRef]

Jiang, Wenying. 2015. Selected Bibliography for the Study of Fiction and Ethics. CLCWeb: Comparative Literature and Culture 17: 15. [CrossRef]

Kaul, Suvir. 2013. Reading, Constraint, and Freedom. The Eighteenth Century 54: 129-32. [CrossRef]

Kraus, Karl. 1932. Die Sprache. Die Fackel. December, 34. Available online: http://languagehat.com/die-fackelonline/ (accessed on 3 February 2020).

Lear, Jonathan. 2008. Radical Hope: Ethics in the Face of Cultural Devastation. Cambridge: Harvard University Press. Lentricchia, Frank, and Andrew Dubois, eds. 2003. Close Reading: The Reader. Durham: Duke University Press.

Levinas, Emmanuel. 1981. Otherwise than Being, or Beyond Essence. Translated by Alphonso Lingis. Pittsburgh: Duquesne University Press.

Levinas, Emmanuel. 1996. Emmanuel Levinas: Basic Philosophical Writings. Edited by Adriaan Theodoor Peperzak, Simon Critchley and Robert Bernasconi. Bloomington: Indiana University Press.

Love, Heather. 2010. Close but not Deep: Literary Ethics and the Descriptive Turn. New Literary History 41: 371-91. [CrossRef]

Makhoul, Marwan. 2007. An Arab at Ben Gurion Airport. Ard al-passiflora al-hazinah [Land of the Sad Passiflora] Beirut: Al-Jamal Publishers, 2007). Translated into English by Raphael Cohen. Available online: http://thetanjara.blogspot.com/2013/01/palestinian-poets-marwan-makhoul-and.html (accessed on 3 February 2020).

Mcdonald, Peter D. 2010. The Ethics of Reading and the Question of the Novel: The Challenge of J. M. Coetzee's Diary of a Bad Year. Novel: A Forum on Fiction 43: 483-99. [CrossRef]

Mendel, Yonatan. 2013. New Jerusalem. New Left Review 81: 35-56.

Meretoja, Hanna. 2018. The Ethics of Storytelling: Narrative Hermeneutics, History, and the Possible. Oxford: Oxford University Press.

Miéville, China Tom. 2010. The City and the City. New York: Random House, pp. 320-21.

Miller, J. Hillis. 1986. The Ethics of Reading: Kant, De Man, Eliot, Trollope, James, and Benjamin. New York: Columbia University Press. 
Moya, Paula M. L. 2015. The Social Imperative: Race, Close Reading, and Contemporary Literary Criticism. Stanford: Stanford University Press.

Newton, Adam Zachary. 1995. Narrative Ethics. Cambridge: Harvard University Press.

Newton, Adam Zachary. 2015. To Make the Hands Impure: Art, Ethical Adventure, the Difficult and the Holy. Fordham: Fordham University Press.

Norris, Andrew. 2014. Thoreau, Cavell, and the Foundations of True Political Expression. In A Political Companion to Henry David Thoreau. Edited by Jack Turner. Louisville: University Press of Kentucky.

Packer, George. 2010. The Unconsoled. The New Yorker. September 27. Available online: https://www.newyorker. com/magazine/2010/09/27/the-unconsoled (accessed on 3 February 2020).

Perloff, Marjorie. 2014. Avant-Garde in a Different Key: Karl Kraus's The Last Days of Mankind. Critical Inquiry 40: 311-38. [CrossRef]

Powers, Peter Kerry. 2008. Deconstruction and Reading. The Chronicle of Higher Education, March 2, vol. 54, B29.

Ricoeur, Paul. 1998. Hermeneutics and the Human Sciences: Essays on Language, Action and Interpretation. Translated by John B. Thompson. Cambridge: Cambridge University Press.

Robbins, Jill. 1999. Altered Reading: Levinas and Literature. Chicago: Chicago University Press.

Rorty, Amelie Oksenberg. 1997. The Ethics of Reading: A Traveler's Guide. Educational Theory 47: 85-89. [CrossRef]

Scarry, Elaine. 2012. Poetry Changed the World: Injury and the Ethics of Reading. Boston Review. July/August. Available online: http://www.bostonreview.net/poetry-arts-culture/poetry-changed-world-elaine-scarry (accessed on 3 February 2020).

Schmidt, Gary. 2008. Reading W.G. Sebald: Adventure and Disobedience. German Quarterly. Hoboken: Wiley, vol. 81, pp. 365-66.

Serpel, Namwali. 2019. The Banality of Empathy. The New York Review of Books. May 19. Available online: https://www.nybooks.com/daily/2019/03/02/the-banality-of-empathy/ (accessed on 3 February 2020).

Stern, J. P. 1966. Karl Kraus's Vision of Language. The Modern Language Review 61: 71-84. [CrossRef]

Stern, David. 1981. Rhetoric and Midrash: The Case of the Mashal. Prooftexts 1: 261-91.

Unger, Roberto Mangabeira. 1984. Passion: An Essay on Personality. New York: Free Press.

Vander Zee, Anton. 2007. Printed Evils and Painted Veils: Anecdote of an Error by Frank Lentricchia. The Wallace Stevens Journal 31: 189-96.

Wood, James. 2010. The Broken Estate: Essays on Literature and Belief. London: Picador. 